\title{
Penerapan guided discovery learning untuk meningkatkan kemampuan berpikir analitis pada materi pengelolaan sumber daya alam siswa kelas XI IPS 1 MA NU Gondanglegi
}

\author{
Alfa Risma Purwita, Budi Handoyo*, Ardyanto Tanjung \\ Universitas Negeri Malang, Jl. Semarang No. 5 Malang, Jawa Timur, Indonesia \\ *Penulis korespondensi, Surel: budi.handoyo.fis@um.ac.id
}

Paper received: 02-03-2021; revised: 15-03-2021; accepted: 30-03-2021

\begin{abstract}
Abstrak
Pembelajaran di dalam kelas tidak lepas dari berbagai macam permasalahan, salah satunya rendahnya kemampuan berpikir analitis. Berdasarkan tes berpikir analitis pra tindakan, peserta didik kelas XI IPS 1 MA NU Gondanglegi memiliki kemampuan berpikir analitis yang rendah dengan rata-rata nilai 64,24. Analisis penyebab rendahnya kemampuan berpikir analitis yang terdiri dari (1) peserta didik; (2) guru; (3) sarana dan prasarana; (4) penerapan strategi pembelajaran, menunjukkan bahwa penerapan strategi pembelajaran merupakan penyebab utama rendahnya kemampuan berpikir analitis peserta didik. Model pembelajaran yang disarankan untuk mengatasi permasalahan tersebut yaitu model Guided Discovery Learning. Dengan demikian, tujuan penelitian ini adalah meningkatkan kemampuan berpikir analitis peserta didik kelas XI IPS 1 MA NU Gondanglegi menggunakan model Guided Discovery Learning. Penelitian ini merupakan Penelitian Tindakan Kelas (PTK) dengan dua siklus yaitu siklus I dan siklus II. Hasil penelitian menunjukkan Guided Discovery Learning dapat meningkatkan kemampuan berpikir analitis. Berdasarkan temuan penelitian menunjukkan nilai rata-rata kemampuan berpikir analitis peserta didik pada siklus I sebesar 72,71 siklus II sebesar 81,88. Hal tersebut menunjukkan adanya peningkatan nilai kemampuan berpikir analitis dari siklus I ke siklus II sebesar 9,18 (12,62 persen). Dengan demikian dapat disimpulkan bahwa penerapan model Guided Discovery Learning dapat meningkatkan kemampuan berpikir analitis peserta didik kelas XI IPS 1 MA NU Gondanglegi. mencakup latar belakang, tujuan, metode yang digunakan, hasil dan kesimpulan.
\end{abstract}

Kata kunci: Guided Discovery Learning, kemampuan berpikir analitis

\section{Pendahuluan}

Dewasa ini pendidikan membutuhkan sebuah proses pembelajaran yang baik. Proses pembelajaran menurut Hamiyah \& Jauhar (2014: 4) yang menyatakan proses pembelajaran adalah suatubproses perubahan perilaku/pribadi seseorang berdasarkan pengalamannya berinteraksi dengan lingkungannya yang ditunjukkan dalam berbagai bentuk seperti perubahan pengetahuan, pemahaman, sikap dan tingkah laku, keterampilan, kecakapan, kebiasaan, serta perubahan aspek-aspek lain yang ada pada individu yang belajar. Dari pendapat tersebut dapat diketahui pembelajaran yang baik harus memenuhi beberapa kriteria, yaitu 1) adanya keterlibatan intelektual-emosional peserta didik, 2) adanya keikutsertaan peserta didik secara aktif dam kreatif, 3) guru bertindak sebagai fasilitator, serta 4) penggunaan metode, alat dan media pembelajaran.

Permasalahan juga dapat terjadi dalam proses pembelajaran. Permasalahan dalam pembelajaran dapat menimbulkan perdebatan, atau keadaan yang masih menimbulkan suatu masalah yang harus dipecahkan (Dendy, 2008:1103). Permasalahan dalam pembelajaran di kelas beragam. Salah satunya adalah rendahnya kemampuan berpikir analitis siswa. Menurut Colin Rose Malcom J. Nicholl (2002:254) berpikir analitis adalah menundukkan satu situasi, 
masalah subjek atau keputusan pada pemeriksaan yang ketat dan langkah demi langkah yang logis. Hal senada juga diungkapkan oleh hardy (2007) berpikir analitis adalah kemampuan berpikir siswa untuk menguraikan, memperinci, dan menganalisis informasi-informasi yang digunakan untuk memahami suatu pengetahuan dengan menggunakan akal dan pikiran yang logis, bukan berdasar perasaan atau tebakan. Sehingga untuk dapat berpikir analitis diperlukan kemampuan berpikir logis dalam mengambil kesimpulan terhadap suatu situasi.

Rendahnya kemampuan berpikir analitis ini juga menjadi permasalahan di MA NU Gondanglegi. Hal tersebut diketahui dari hasil observasi pada akhir Agustus 2018, bahwa peserta didik belum mampu berpikir analitis dalam suatu topik pembelajaran Geografi. Hal tersebut dibuktikan dari nilai kemampuan berpikir analitis siswa pada awal semester gasal yaitu pada materi Posisi strategis Indonesia sebagai Poros Maritim Dunia yang tergolong masih rendah. Jawaban-jawaban peserta didik dari soal analitis yang diberikan masih terbatas pada pengertian-pengertian yang mereka hafalkan. Hasil rata-rata dari nilai siswa di kelas XI IPS 1 adalah 64,24 (nilai keseluruhan dapat dilihat pada lampiran nilai pra tindakan).

Analisis penyebab rendahnya kemampuan berpikir analitis siswa perlu dilakukan. Analisis tersebut dapat dikaji melalui kondisi nyata yang terjadi di kelas. Analisis ini merujuk pada empat aspek, yaitu (1) peserta didik; (2) guru; (3) sarana dan prasarana; (4) penerapan strategi pembelajaran. Pembelajaran yang dilakukan masih berpusat pada guru, dimana guru masih memberikan materi pelajaran dengan cara konvensional malalui ceramah. Dengan demikian strategi pembelajaran merupakan penyebab dari rendahnya kemampuan berpikir analitis siswa.

Salah satu model pembelajaran yang mendukung siswa untuk dapat mengembangkan kemampuan berpikir analitisnya yaitu Guided Discovery Learning. Model Guided Discovery Learning ini memiliki beberapa kelebihan. Pertama, pembelajaran ini mampu meningkatkan kemampuan penalaran serta berpikir analitis. Kedua, pembelajaran ini dapat melatih keterampilan kognitif siswa untuk menemukan dan memecahan masalah secara mandiri. Ketiga, pembelajaran ini penerapannya secara terbimbing sehingga siswa akan lebih mudah dalam mencapai tujuan pembelajaran. Keempat, pembelajaran berbasis penemuan ini akan membuat pengetahuan siswa bertahan lebih lama serta mudah untuk diingat. Kelima, pembelajaran Guided Discovery Learning belum pernah diterapkan oleh guru pamong Geografi di MA NU Gondanglegi.

Pada tahun 2016 Muhimatul Ulum telah melaksanakan penelitian tindakan kelas yaitu mengenai Penerapan Model Pembelajaran Discovery untuk Meningkatkan Kemampuan Berpikir Kritis Siswa pada Mata Pelajaran Geografi Kelas XI-IIS2 MAN 1 Malang. Hasil penelitian yang telah dilakukan menunjukkan adanya peningkatan kemampuan berpikir kritis siswa yang diketahui dari hasil tes kemampuan berpikir kritis. Pada tahun 2017 Ari Enggarwati telah melaksanakan penelitian tindakan kelas yaitu mengenai Penerapan Model Discovery Untuk Meningkatkan Kemampuan Berfikir Analitis Siswa Pada Kelas XI IPS3 SMAN 7 Malang Semester Genap Tahun Ajaran 2016/2017. Berdasarkan hasil penelitian diperoleh kesimpulan bahwa pembelajaran model discovery learning dapat meningkatkan kemampuan berfikir analitis siswa kelas XII IPS 3 SMAN 7 Malang semester genap tahun ajaran 2016/2017.

Tujuan dari penelitian ini yaitu untuk mengetahui penerapan Guided Discovery Learning dapat meningkatkan kemampuan berpikir analitis pada materi pengelolaan sumber daya alam siswa kelas XI IPS 1 MA NU Gondanglegi. 


\section{Metode}

Penelitian ini termasuk dalam penelitian tindakan kelas (PTK). Penelitian ini dilaksanakan pada semester gasal tahun ajaran 2018/2019 (bulan agustus sampai bulan desember 2018) dan dibagi dalam 2 siklus. Siklus I dilaksankan selama 6 jam pelajaran atau dua kali pertemuan. Siklus II juga dilaksanakan selama 6 jam pelajaran atau dua kali pertemuan. Penelitian dilakukan di MA NU Gondanglegi. Subjek penelitian adalah siswa kelas XI IPS 1 Semester gasal tahun ajaran 2018/2019 berjumlah 32 Siswa. Data yang dikumpulkan merupakan aktivitas guru dan siswa selama penerapan model pembelajaran Guided Discovery berlangsung. Hasil tes kemampuan berpikir analitis siswa dilaksanakan setiap akhir siklus. Sumber data dalam penelitian ini adalah siswa kelas XI IPS 1 untuk memperoleh data mengenai kemampuan berpikir analitis pada materi Sumber Daya Alam.

Instrumen penelitian yang digunakan dalam penelitian ini terdiri dari instrumen pengumpulan data dan instrumen tindakan, yaitu instrumen pengumpulan data dan intrumen tindakan. Instrumen tindakan adalah alat yang digunakan untuk memperoleh data hasil pelaksanaan pembelajaran yang terdiri dari: Lembar observasi keterlaksanaan pembelajaran Guided Discovery, Lembar diskusi kelompok dan Catatan lapangan. Teknik pengumpulan data yang digunakan yaitu dengan menggunakan pengumpulan data pelaksanaan tindakan dan pengumpulan data penelitian. Hasil yang didapat menjadi tolak ukur dalam penentuan kemampuan berpikir analitis siswa, yang dapat digolongkan dalam kualifikasi nilai kemampuan berpikir analitis siswa dalam setiap siklus yang dilakukan. Kualifikasi kemampuan berpikir analitis siswa dapat diketahui dari tabel berikut.

Tabel 1. Kualifikasi Nilai Kemampuan Berpikir Analitis

\begin{tabular}{lll}
\hline Klasifikasi & Kualifikasi & Rentang Nilai \\
\hline A & Sangat Baik & $85-100$ \\
B & Baik & $70-84$ \\
C & Cukup Baik & $55-69$ \\
D & Kurang Baik & $50-54$ \\
E & Sangat Kurang Baik & $0-49$ \\
\hline
\end{tabular}

Sumber Arikunto, 2010:65

Hasil tes yang telah diklasifikasikan kemudian menjadi bahan analisa kemampuan berpikir analitis siswa. Analisa kemampuan berpikir analitis dapat diketahui melalui perhitungan menggunakan rumus sebagai berikut:

Rata-rata kemampuan berpikir analitis siswa $=\frac{\Sigma \text { Skor Seluruh Siswa }}{\Sigma \text { Siswa Keseluruhan }}$

Sumber: Arikunto, 2010:183

\section{Hasil dan Pembahasan}

Hasil Penelitian yaitu data hasil tes kemampuan berpikir analitis pra tindakan dan pasca tindakan siklus I dan II. Berikut penjelasan mengenai kemampuan berpikir analitis siswa pada pra tindakan sampai dengan pasca tindakan serta peningkatan nilai yang didapatkan. 
Tabel 2. Kemampuan Berpikir Analitis Pra Tindakan

\begin{tabular}{lllll}
\hline Klasifikasi & Kualifikasi & Rentang Nilai & Frekuensi & Persentase \% \\
\hline A & Sangat Baik & $85-100$ & 1 & 2,94 \\
B & Baik & $70-84$ & 10 & 29,41 \\
C & Cukup & $55-69$ & 7 & 20,59 \\
D & Kurang Baik & $50-54$ & 16 & 47,06 \\
E & Sangat Kurang & $0-49$ & 0 & 0 \\
& Baik & & 34 & 100 \\
\hline Jumlah & & &
\end{tabular}

Berdasarkan tabel tersebut, diketahui bahwa sebagian peserta didik (32,35\%) mendapatkan nilai kemampuan berpikir analitis dengan kualifikasi baik sampai sangat baik. Sedangkan $(20,59 \%)$ peserta didik dikategorikan cukup, dan $(47,06 \%)$ peserta didik yang dapat dikualifikasikan dalam kurang. Berikut adalah grafik perbandingan hasil kelima kulifikasi kemampuan berpikir analitis siswa nilai sebelum dilakukan tindakan penerapan model pembelajaran Guided Discovery dengan menggunakan lembar kegiatan siswa.

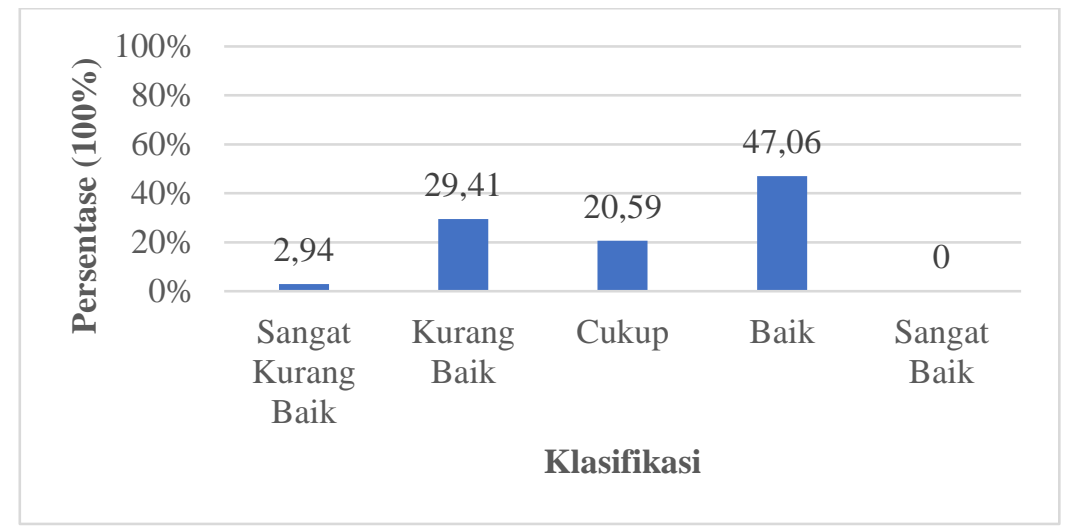

\section{Grafik 1. Distribusi Frekuensi Pra-Tindakan Penerapan Guided Discovery Learning}

Perolehan nilai kemampuan berpikir analitis siklus I dapat dilihat pada lampiran, sedangkan distribusi nilai siklus I kemampuan berpikir analitis siswa kelas XI IPS 1 dapat dilihat pada tabel berikut ini.

Tabel 3. Kemampuan Berpikir Analitis Siklus I

\begin{tabular}{lllll}
\hline Klasifikasi & Kualifikasi & Rentang Nilai & Frekuensi & Persentase \% \\
\hline A & Sangat Baik & $85-100$ & 4 & 11,76 \\
B & Baik & $70-84$ & 16 & 47,06 \\
C & Cukup & $55-69$ & 14 & 41,18 \\
D & Kurang Baik & $50-54$ & 0 & 0 \\
E & Sangat Kurang & $0-49$ & 0 & 0 \\
& Baik & & 34 & 100 \\
\hline Jumlah & & & \\
\hline
\end{tabular}

Berdasarkan tabel tersebut, diketahui bahwa sebagian peserta didik $(58,82 \%)$ mendapatkan nilai kemampuan berpikir analitis dengan kualifikasi baik sampai sangat baik. 
Sedangkan (41,18\%) peserta didik dikategorikan cukup. Adapun grafik kemampuan berpikir analitis siswa sebagai berikut.

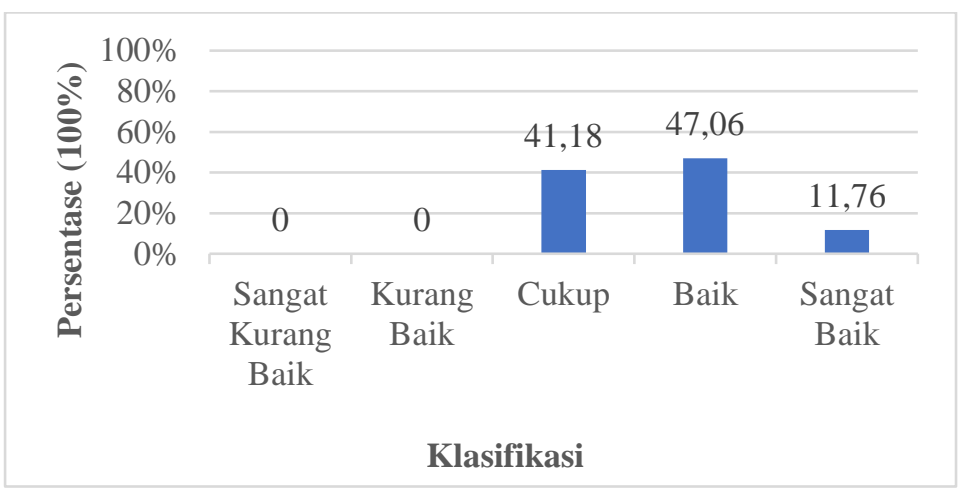

\section{Grafik 2. Distribusi Frekuensi Siklus I Penerapan Guided Discovery Learning}

Perolehan nilai kemampuan berpikir analitis siklus I dapat dilihat pada lampiran, sedangkan distribusi nilai siklus I kemampuan berpikir analitis siswa kelas XI IPS 1 dapat dilihat pada tabel berikut ini.

Tabel 4. Kemampuan Berpikir Analitis Siklus II

\begin{tabular}{lllll}
\hline Klasifikasi & Kualifikasi & Rentang Nilai & Frekuensi & Persentase \% \\
\hline A & Sangat Baik & $85-100$ & 15 & 38,23 \\
B & Baik & $70-84$ & 19 & 55,88 \\
C & Cukup & $55-69$ & 0 & 0 \\
D & Kurang Baik & $50-54$ & 0 & 0 \\
E & Sangat Kurang & $0-49$ & 0 & 0 \\
\hline Jumlah & Baik & & 34 & 100 \\
\hline
\end{tabular}

Berdasarkan tabel tersebut, diketahui bahwa sebagian peserta didik $(94,11 \%)$ mendapatkan nilai kemampuan berpikir analitis dengan kualifikasi baik sampai sangat baik. Sedangkan $(5,89 \%)$ peserta didik dikategorikan cukup. Berdasarkan grafik tersebut, peserta didik yang mendapatkan nilai dengan kualifikasi sangat tinggi sudah 13 siswa. Hal ini menandakan kemampuan berpikir analitis di kelas XI IPS 1 sudah menjadi lebih baik. . Adapun grafik kemampuan berpikir analitis siswa sebagai berikut.

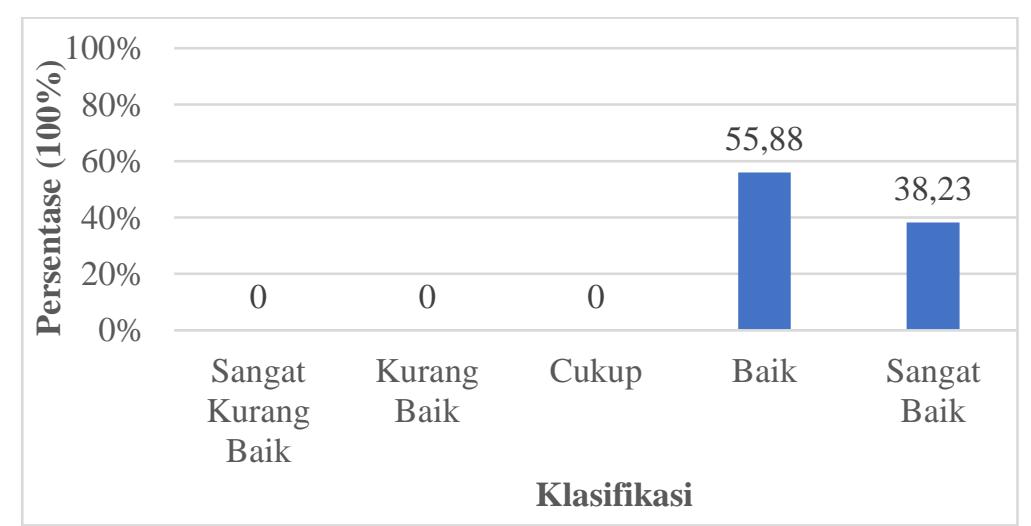

Grafik 3. Distribusi Frekuensi Siklus II Penerapan Guided Discovery Learning 
Analisis data kemampuan berpikir analitis siswa kelas XI IPS 1 dilakukan dengan cara membandingkan nilai tes akhir pada pra-tindakan, siklus I, dan siklus II. Analisis data juga dapat menjelaskan dan menginformasikan keberhasilan penerapan model pembelajaran Guided Discovery. Adapun data perbandingan Persentase Kemampuan Berpikir Analitis Pra Tindakan, Siklus I, dan Siklus II dapat dilihat pada tabel berikut.

Tabel 5. Perbandingan Persentase Kemampuan Berpikir Analitis Pra Tindakan, Siklus I, dan Siklus II

\begin{tabular}{|c|c|c|c|c|c|c|c|c|}
\hline \multirow[b]{2}{*}{$\begin{array}{l}\text { Klasi } \\
\text { fikasi }\end{array}$} & \multirow[b]{2}{*}{ Nilai } & \multirow[b]{2}{*}{ Kualifikasi } & \multicolumn{3}{|c|}{ Frekuensi } & \multicolumn{3}{|c|}{ Persentase (\%) } \\
\hline & & & $\begin{array}{l}\text { Pra } \\
\text { Tindakan }\end{array}$ & $\begin{array}{l}\text { Siklus } \\
\text { I }\end{array}$ & $\begin{array}{l}\text { Siklus } \\
\text { II }\end{array}$ & $\begin{array}{l}\text { Pra } \\
\text { Tindak } \\
\text { an }\end{array}$ & $\begin{array}{l}\text { Siklus } \\
\text { I }\end{array}$ & Siklus II \\
\hline A & $\begin{array}{l}80- \\
100\end{array}$ & Baik Sekali & 1 & 4 & 15 & 2,94 & 11,76 & 38,23 \\
\hline B & $60-79$ & Baik & 10 & 16 & 19 & 29,41 & 47,06 & 55,88 \\
\hline $\mathrm{C}$ & $40-59$ & Cukup Baik & 7 & 14 & 0 & 20,59 & 41,18 & 0 \\
\hline $\mathrm{D}$ & $20-39$ & $\begin{array}{l}\text { Kurang } \\
\text { Baik }\end{array}$ & 16 & 0 & 0 & 47,06 & 0 & 0 \\
\hline $\mathrm{E}$ & $0-19$ & Tidak Baik & 0 & 0 & 0 & 0 & 0 & 0 \\
\hline Jumlah & & & 34 & 34 & 34 & 100 & 100 & 100 \\
\hline
\end{tabular}

Perbandingan Persentase Kemampuan Berpikir Analitis Pra Tindakan, Siklus I, dan Siklus II secara lebih jelas dapat dilihat dari grafik berikut.

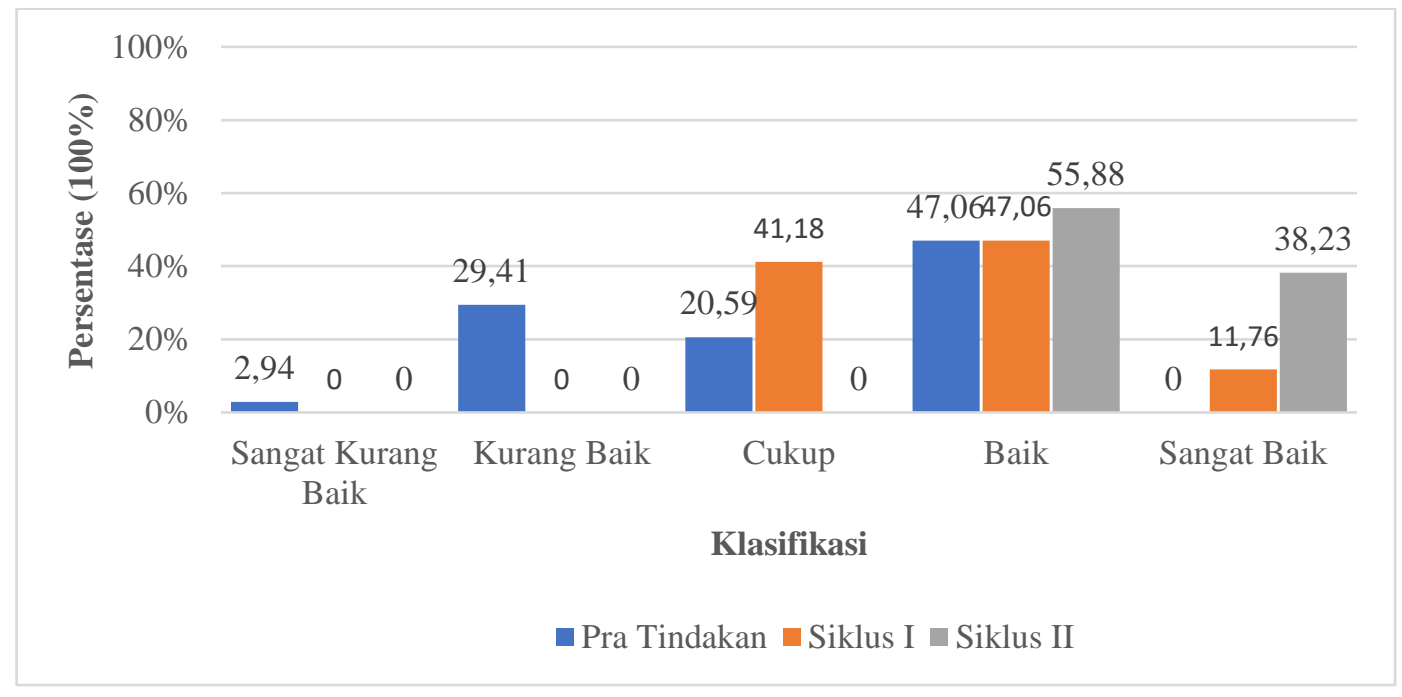

\section{Grafik 4. Perbandingan Persentase Kemampuan Berpikir Analitis Pra Tindakan, Siklus I, dan Siklus II}

Berdasarkan tes kemampuan berpikir analitis yang dilakukan, diketahui bahwa nilai kemampuan bepikir analitis siswa pada siklus I adalah 72,71. sedangkan nilai siklus II 81,88 . Dengan demikian peningkatan rata-rata dari siklus I ke II adalah 9,18. Presentase peningkatan kemampuan berpikir analitis adalah $12,62 \%$. untuk lebih jelasnya dapat dilihat pada tabel berikut. 
Jurnal Integrasi dan Harmoni Inovatif Ilmu-Ilmu Sosial (JIHI3S), 1(3), 2021, 326-335

Tabel 6. Perbandingan Rata-rata Nilai Kemampuan Berpikir Analitis Siswa

\begin{tabular}{lll}
\hline Pelaksanaan Tindakan & $\begin{array}{l}\text { Rata-rata nilai kemampuan } \\
\text { berpikir analitis siswa }\end{array}$ & Persentase Peningkatan \\
\hline Pra Tindakan & 64,24 & \\
Siklus I & 72,71 & \\
Siklus II & 81,88 & $12,62 \%$ \\
\hline
\end{tabular}

Dari grafik diatas diketahui bahwa rata-rata nilai kemampuan berpikir analitis siklus I ke II mengalami peningkatan. Jadi, temuan dari penelitian ini yaitu model Guided Discovery Learning mampu meningkatkan kemampuan berpikir analitis siswa.

Penelitian ini mendapatkan hasil berupa temuan penelitian. Temuan dari penelitian ini yaitu adanya peningkatan kemampuan berpikir analitis siswa kelas XI IPS 1 MA NU Gondanglegi. Dengan kata lain, terdapat penigkatan setelah adanya tindakan penerapan model Guided Discovery Learning terhadap kemampuan berpikir analitis pada mata pelajaran Geografi kelas XI IPS 1 MA NU Gondanglegi. Hal tersebut dapat diketahui dari hasil tes kemampuan berpikir analitis pada siklus I dan II.

Adanya peningkatan hasil kemampuan berpikir analitis peserta didik dikarenakan beberapa hal yaitu metodologi yang digunakan dan keterkaitan antara kelebihan model pembelajaran Guided Discovery Learning dengan faktor-faktor kemampuan berpikir analitis. Meningkatnya kemampuan berpikir analitis peserta didik erat kaitannya dengan metodologi penelitian yang dilakukan oleh peneliti. Peserta didik diberikan tindakan berupa pengalaman langsung ke lapangan untuk menemukan pemecahan baru dari suatu permasalahan yang diberikan guru, berdasarkan pemikiran dan analisa mereka. Hal ini didukung dengan panduanpanduan yang terdapat dalam Lembar Kerja Peserta Didik kelompok. Peserta didik dapat menyelesaikan LKPD tersebut dengan baik dan terstruktur.

Instrumen penelitian juga menunjang tercapainya peningkatan kemampuan berpikir analitis peserta didik pada siklus I. Instrumen penelitian ini meliputi lembar kemampuan berpikir analitis, lembar observasi dan catatan lapangan. Ketiga instrumen tersebut telah disusun dengan cukup baik sehingga proses pengumpulan data penelitian dapat dilakukan dengan lancar. Data yang telah terkumpul digunakan sebagai bahan refleksi sebagai acuan perbaikan pada siklus berikutnya.

Selain metodologi, keterkaitan antara model Guided Discovery Learning dengan faktorfaktor kemampuan berpikir analitis juga dapat meingkatkan kemampuan berpikir analitis. Keterkaitan pertama kelebihan model Guided Discovery Learning siswa dilatih untuk memperbaiki dan memberdayakan keterampilan dan proses kognitifnya. Kognitif berhubungan dengan atau melibatkan kognisi. Sedangkan kognisi merupakan kegiatan atau proses memperoleh pengetahuan (termasuk kesadaran, perasaan, dsb) atau usaha mengenali sesuatu melalui pengalaman sendiri. Kemampuan kognitif adalah penampilan-penampilan yang dapat diamati sebagai hasil-hasil kegiatan atau proses memperoleh pengetahuan melalui pengalaman sendiri. Menurut Anas Sudijono (2001: 49) ranah kognitif adalah ranah yang mencakup kegiatan mental (otak). R o b e r t M . Gagne dalam W. S .Winkel (1996: 102) juga menyatakan bahwa "ruang gerak pengaturan kegiatan kognitif adalah aktivitas mentalnya 
sendiri." Lebih lanjut Gagne menjelaskan bahwa "pengaturan kegiatan kognitif mencakup penggunaan konsep dan kaidah yang telah dimiliki, terutama bila sedang menghadapi suatu problem." Pendapat-pendapat tersebut mendukung pernyataan bahwa Guided Discovery Learning mampu melatih dan memperbaiki kognitif siswa melalui pembelajaran dengan melibatkan siswa secara langsung untuk mengkaji dan memecahkan suatu permasalahan melalui penemuan mandiri.

Keterkaitan kedua model Guided Discovery Learning yaitu siswa dilatih untuk memiliki kemampuan berpikir analitis melalui penemuan baru dalam memecahkan sebuah permasalahan. Siswa dilatih untuk memiliki kemampuan berpikir analitis untuk menemukan temuan baru dalam memecahkan permasalahan dalam topik permasalahan pada saat diskusi kelompok. Dengan adanya permasalahan, siswa dituntut untuk melakukan pengolahan data dan menganalisis data serta membuat kesimpulan dan solusi terhadap suatu permasalahan. Menurut Made Wena menyatakan bahwa "idealnya aktivitas pembelajaran tidak hanya difokuskan untuk mendapatkan pengetahuan sebanyak-banyaknya, melainkan juga bisa menggunakan segenap pengetahuan yang dididapat untuk menghadapi situasi baru atau memecahkan masalah-masalah khusus yang berkaitan dengan pembelajaran" (Wena, 2008). Pembelajaran berbasis penemuan akan bermanfaat bagi siswa untuk dapat mengingat materi lebih lama, sehingga pembelajaran tersebut dapat digunakan di masa depan sebagai pengalaman bermakna.

Keterkaitan ketiga kelebihan Guided Discovery Learning yaitu memberi pengalaman mengembangkan keingintahuan mereka. Kegiatan pembelajaran dengan menggunakan Guided Discovery Learning siswa tidak hanya mendapatkan pengalaman bekerja secara kooperatif dalam kelompok. Pengalaman lainnya yaitu siswa juga akan belajar bagaimana membuat hipotesis, melakukan penyelidikan, menganalisis data, dan membuat temuan baru untuk memecahkan masalah. Keadaan tersebut menunjukkan bahwa model Guided Discovery Learning dapat memberikan pengalaman baru yang kaya kepada siswa.

Ketarkaitan keempat yaitu siswa belajar secara mandiri. Kemandirian dalam belajar menjadi bekal penting bagi siswa untuk menjalani hidup dan kehidupan setelah mereka terjun ke tengah masyarakat kelak di kemudian hari. Mereka akan menjadi pribadi yang mandiri dalam menghadapi dan memecahkan masalah yang dihadapi. Kegiatan pembelajaran yang dapat menjadikan siswa mandiri yaitu pembelajaran berbasis penemuan. Dengan adanya proses penemuan siswa akan lebih termotivasi untuk mengaplikasikan pengetahuan dimiliki serta berusaha mencari pengetahuan yang diperlukan.

Hasil penelitian ini mendukung penelitian terdahulu. Penelitian tersebut mengkaji model Guided Discovery Learning, seperti yang dilakukan Irwan Supriyono dengan judul "Pengaruh Model Guided Discovery Learning terhadap Kemampuan Berpikir Analitis Siswa Kelas XI SMA Negeri Klakah". Hasil penelitian menunjukkan,bahwa nilai sig (2-tailed) adalah $0.008<0.05$ dan rata-rata nilai gain score kelas eksperimen 13,09 lebih besar dari nilai ratarata kelas kontrol 6,56. Maka H0 ditolak atau dengan kata lain model pembelajaran penemuan terbimbing berpengaruh terhadap kemampuan berpikir analitis siswa kelas XI SMA Negeri Klakah. Dari penelitian tersebut diketahui model Guided Discovery Learning berpengaruh terhadap kemampuan berpikir analitis siswa.

Berdasarkan uraian diatas dapat disimpulkan bahwa temuan dalam penelitian ini yaitu terdapat peningkatan kemampuan berpikir analitis setelah adanya tindakan menggunakan 
model Guided Discovery Learning terhadap kemampuan berpikir analitis pada mata pelajaran Geografi siswa kelas XI IPS 1 MA NU Gondanglegi

\section{Simpulan}

Berdasarkan rumusan masalah dan hasil penelitian dapat disimpulkan bahwa penerapan Guided Discovery Learning dapat meningkatkan kemampuan berpikir analitis siswa pada materi pengelolaan sumber daya alam kelas XI IPS 1 MA NU Gondanglegi dengan presentase peningkatan kemampuan berpikir analitis yaitu sebesar $12,62 \%$.

Berdasarkan kesimpulan diatas, maka saran yang dapat diajukan peneliti yaitu:

\section{Bagi Guru Geografi}

Berdasarkan hasil penelitian, model Guided Discovery Learning terbukti dapat meningkatkan kemampuan berpikir analitis. Para guru geografi disarankan untuk menerapkan model Guided Discovery Learning di kelas terutama pada mata pelajaran Geografi. Guru harus membuat RPP yang sesuai dan menerpakannya melalui langkah-langkah dari model Guided Discovery Learning. Untuk menggunakan model Guided Discovery Learning guru disarankan melakukan hal-hal sebagai berikut:

a) Guru hendaknya mengetahui kelamahan dan kelebihan dalam penerapan model Guided Discovery Learning.

b) Guru mampu menyesuaikan materi dengan model Guided Discovery Learning, karena tidak semua materi pembelajaran Geografi dapat diterapkan dalam penelitian.

c) Guru harus mampu mengatur waktu apabila pelaksanaan dari salah satu tahap pembelajaran ada yang melebihi alokasi waktu yang telah ditentukan.

2. Bagi Peneliti Lanjut

Saran bagi peneliti selanjutnya yang ingin melakukan penelitian tentang model pembelajarn Guided Discovery Learning, disarankan melakukan hal-hal berikut:

a) Peneliti lanjut hendaknya mengtahui kelebihan dan kelemahan penerpaan model Guided Discovery Learning.

b) Perlu penyesuaian materi dengan model pembelajaran.

c) Membuat RPP yang sesuai.

d) Peneliti sebagai pengajar harus mampu mengkondisikan kelas

\section{Daftar Rujukan}

Anas Sudijono. (2001). Pengantar Ealuasi Pendidikan. Jakarta. RajaGrafindo Persada.

Arikunto, Suharsimi. (2010). Prosedur Penelitian: Suatu Pendekatan Praktik. Edisi: revisi. Jakarta: Rineka Cipta. Dendy, Sugono. (2008). Kamus Besar Bahasa Indonesia Edisi Keempat. Jakarta: Gramedia.

Hamiyah, N. Dan M. Jauhar. (2014). Strategi Belajar-Mengajar di Kelas. Jakarta: Prestasi Pustaka.

Rose, C. \& Nicholl, M.J. (2012). Accelerated Learning. Terj. Dedy Ahimsa. Bandung: Nuansa. (Buku asli diterbitkan 1997).

Sudijono, Anas. (2011). Evaluasi Pedidikan. Jakarta: Raja Grafindo Persada.

Supriyono, Irwan. (2011). Pengaruh Model Guided Discovery Learning terhadap Kemampuan Berpikir Analitis Siswa Kelas XI SMA Negeri Klakah. Skripsi Universitas Negeri Malang.

Tim Pelatih Proyek PGSM. 1999. Penelitian Tindakan Kelas. Departemen Pendidikan Dan Kebudayaan, Direktorat Jenderal Pendidikan Tinggi.

Trianto. 2011. Mendesain Model Pembelajaran Inovatif-Progesif. Jakarta: Kencana.

Wena, Made. (2008). Strategi Pembelajaran Inovatif Kontemporer. Jakarta: Bumi Aksara. 
Jurnal Integrasi dan Harmoni Inovatif Ilmu-Ilmu Sosial (JIHI3S), 1(3), 2021, 326-335

W.S. Winkel. (1996). Psikologi Pengajaran. Jakarta: Gramedia. Ari, Enggarwati. 2017. Penerapan Model Discovery Untuk Meningkatkan Kemampuan Berfikir Analitis Siswa Pada Kelas XI IPS3 SMAN 7 Malang Semester Genap Tahun Ajaran 2016/2017. Skripsi, Jurusan Geografi, Falkutas Ilmu Sosial. Universitas Negeri Malang. 